\title{
Teaching and learning English language - motivation
}

\author{
Sashka Jovanovska ${ }^{1}$ \\ ${ }^{l}$ PhD, English professor, North Macedonia \\ Email:_saska_dimitrovska@yahoo.com
}

\begin{abstract}
Learning a new language can be difficult, so teaching a new language inherently comes with great obstacles. To effectively teach English to someone new to the language, you have a lot to understand, including the basics of the English language, how speakers acquire a new language, and how to motivate students to succeed when they are struggling. The focus on this paper is on the basics of how to get started, including taking a hard look at how to access the motivations of new students, how to use their previous language and cultural background to your advantage, and how to get them started on the path to English fluency.
\end{abstract}

Keywords: Second Language Acquisition, Second Language Learning, Motivation, Age.

\section{INTRODUCTION}

Teaching any subject involves knowing how motivation affects a student. Without proper motivation, it will be difficult for students to accept what they are learning and commit to the process. Since learning a new language can especially hard, it is even more important that you, as the teacher, understand the motivation behind the student's commitment to learning, and use it to your advantage.

\section{INTRINSIC MOTIVATION}

Intrinsic motivation is the best stepping stone to success, but you can't teach it. Intrinsic motivation characterizes someone who is compelled to do something for internal rewards. This type of motivation is powerful because extrinsic rewards can be fleeting or disappointing, but an internal drive to succeed will almost always motivate an individual. While you cannot teach someone to be intrinsically motivated, you can help the students access intrinsic motivation they may not know is already there, or that they may have lost for the moment. If you know your students are intrinsically motivated, you can help them succeed. Here are some tips:

- Get to the root of what is driving the individual. While they may only acknowledge an extrinsic motivation for learning English, you may be able to help them tie that to a grander internal drive. For example, if students come to you wanting to learn English because they are moving to an English-speaking country and it will be helpful to know the language, the superficial part of their reasoning points toward extrinsic motivation. However, this extrinsic motivator points to something internal: the desire to fit in and not feel like an outsider.

- Understand the basis for most forms of intrinsic motivation. William Glasser, an American psychiatrist, published a theory in 1998 proposing that humans have essential needs that dictate our emotional health. These needs are the need to belong or connect, the need for power or competence, the need for freedom, and the need to have fun. Having these needs in mind could help you when designing your lessons. Which of these needs is this lesson satisfying? This is a way to get away from the punishment and reward system that is meant to access an individual's extrinsic motivation.

- Be aware that intrinsic motivation cannot be forced, and does not abide by the classic reward and punishment system that many people follow. For example, if someone is not reacting to your lessons, it is not going to be helpful to intentionally make them feel that they don't belong. For intrinsic motivation to succeed, the individual needs to feel like he or she is in control of the situation, so try to access your students' internal drive, but don't force them. 


\section{EXTRINSIC MOTIVATION}

While extrinsic motivation is not nearly as strong as intrinsic motivation, it is much easier, as the teacher, for you to control. Extrinsic motivation refers to when an individual is compelled to do something because of an outside reward. Because of the ease it can be used to teach someone, extrinsic motivators are often the basis for educational programs. The most common extrinsic motivator is grades, which teachers can simply reward good behavior and punish bad behavior (behavior here refers to whatever the student is expected to do). A student who hands in their project, follows directions, and effectively addresses the purpose of the project is rewarded with an A, and a student who does not is punished with an F.

\section{Why it works}

Even though the drive caused by extrinsic motivation pales in comparison to intrinsic motivation, that doesn't mean that you cannot find success with extrinsic motivation. These motivators access an individual's desire to find success even if someone else defines that success. Here are some examples of extrinsic motivators that work in the classroom:

- Grades: This is the most obvious extrinsic motivator. Individuals want to be successful and feel better when they receive a high score as opposed to a low score. If you teach in a high school setting, grades can mean the difference as to whether or not the student gets into college (or a good college), so grades can be a good motivator for students. Even when there is no next level, however, many students will be motivated to succeed by grades.

- Competition: Many individuals have an innate desire to be winners, and putting your students in competition with each other can be a good way to motivate them to succeed, especially if the ongoing results are available to all students. This approach often used by teachers of younger students with such things as performance charts, where teachers give students who do well some sort of visible reward, such as a gold star. Conversely, teachers can punish negative behaviors by posting the name of the student in question on the board as someone who is not behaving. This can sometimes help motivate students to succeed because they would like to do better than their classmates.

- Extra rewards and punishments: Besides grades, some teachers will offer extra incentive to succeed, perhaps in the form of prizes. A teacher might, for example, make an agreement with a student that if he or she improves, then he or she can go on the class trip. Conversely, punishments such as detentions or phone calls home can be a consequence that motivates a student.

Kristmanson (2000), offers that an effective learning environment can be achieved by:

$>$ Encouraging and supporting students at all times but especially when they are struggling or lacking confidence in certain areas.

$>$ Being energetic and enthusiastic about what you are teaching and on those days when you do not have that energy, provide activities that require the learners to put forth the majority of the energy.

$>$ Creating an atmosphere in which students are not afraid to make mistakes and are encouraged to take risks.

> Avoiding tension-causing strategies such as surprise quizzes, overly competitive activities, putting students in front of their peers with no warning or chance for preparation, and correcting errors in a negative, accusatory fashion.

$>$ Allowing students opportunities to talk about themselves, their interests, and their culture.

$>$ Providing opportunities for interaction in the target language in and outside the language learning environment through preplanned and spontaneous activities,

$>$ Encouraging goal setting and a sense of dedication and continuous commitment to the language learning task through meaningful, relevant and authentic language learning activities.

$>$ Encouraging learners to seek out opportunities in their lives that will help in the learning of the target language.

$>$ Creating, through the presentation of attainable goals and reasonable challenges, a learning environment with a definite potential for success. 


\section{CONCLUSION}

The success in second language acquisition depends on many factors. Age and motivation factors are among the most important ones. In studies, it has been found that if a learner has a competency in his or her own language, he or she is more advantageous than those who have not completed his first language. As to motivation, it has been found that motivated students are more successful in second language acquisition second language acquisition than those who are not motivated.

\section{REFERENCES}

1. Collier, V. P. (1988). The Effect of Age on Acquisition of a Second Language for School. New Focus. The National Clearinghouse for Bilingual Education. No: 2, Winter: 1987-1988.

2. Cooper, P. \& McIntyre D. (1998). Effective Teaching and Learning. Teachers' and Students' Perspectives. Open University Press. Great Britain: Biddles Limited, Guildford and King's Lynn.

3. Crookes, G. \& Schmidt, R. (1991). Motivation: Reopening the Research Agenda. Language Learning 41: 469-512.

4. Davies, C. (1996). What is English Teaching? English, Language, and Education Series. Open University Press. Great Britain: Biddles Ltd, Guildford and Kings Lynn.

5. Dörnyei Z. (1994). Motivation and Motivating in the Foreign Language Classroom, The Modern Language Journal, 78: 273-284.

6. Ervin-Tripp, S. M. (1974). Is Second Language Learning Like the First? TESOL Quarterly, 8, 111-127. (NCBE Abstract).

7. Fathman, A. (1975). The Relationship Between Age and Second Language Productive Ability, Language Learning. 21, 245-253.

8. Gardner, R.C., \& MacIntyre, P.D. (1991). An Instrumental Motivation in Language Study: Who says it isn't effective? Studies in Second Language Acquisition, 13, 57-72.

9. Gardner, R.C., Lalonde, R.N., and Moorcroft, R. (1985). The Role of Attitudes and Motivation in Second Language Learning: Correlational and Experimental Considerations. Language Learning, 35, 207-227.

10. Krashen, S. (1982). Principles and Practice in Second Language Acquisition. Oxford: Pergamon Press.

11. Krashen, S. (1985). The Input Hypothesis: Issues and Implications. New York: Longman.

12. Kristmanson, P. (2000). Affect in the Second Language Classroom: How to Create an Emotional Climate. Reflexions May//mai 2000 Vol. 19 No. 2

13. Lenneberg, E. (1976). Biological Foundations of Language. New York: John Wiley and Sons.

14. McLaughlin, B. (1984). Second Language Acquisition in Childhood. Vol. 1. Preschool Children.(2nd edition). Hillsdale, NJ: Lawrence Erlbaum Associates.

15. Oxford, R. \& Shearin, J. (1994). Language Learning Motivation: Expanding the Theoretical Framework. The Modern Language Journal 78: 12-28.

16. Reece, I \& Walker, S. (1997). Teaching, Training and Learning. A Practical Guide. (Third Ed.). Great Britain: Business Education Publishers Limited.

17. Shulman, L. (1986). Paradigms and Research Programmes in the Study of Teaching'. In M. Wittrock (ed.). Handbook of Research on Teaching, London: Mcmillan.

18. Skehan, P. (1991). Individual Differences in Second Language Learning. Studies in Second Language Acquisition 13: 275-298.

19. Williams, L. (1979). The Modification of Speech Perception and Production in Second Language Learning. Perception and Psychophysics, 26 (2), 95-105. 